研

\title{
EDTA 浴による高速度無電解銅めっきの反応機構
}

\author{
斎藤囲*本間 英 夫* \\ Mechanisms of High-Speed Electroless Copper Deposition from EDTA Bath
}

Mamoru SAITO* and Hideo HONMA*

\begin{abstract}
Mechanisms of high-speed electroless copper deposition from EDTA bath were investigated by means of analytical method, X-ray diffraction and electrochemical method. From the analysis of bath components and the reaction products such as copper and hydrogen gas during the electroless copper deposition at $70^{\circ} \mathrm{C}$, it was confirmed that the following reactions were occurring in the bath.

$\mathrm{Cu}$ deposition reaction : $\mathrm{Cu}(\mathrm{II})-\mathrm{EDTA}+2 \mathrm{HCHO}+4 \mathrm{OH}^{-} \rightarrow \mathrm{Cu}+2 \mathrm{HCOO}^{-}+\mathrm{H}_{2}+2 \mathrm{H}_{2} \mathrm{O}+\mathrm{EDTA} \cdots(1)$

Cannizzaro reaction : $2 \mathrm{HCHO}+\mathrm{OH}^{-} \rightarrow \mathrm{CH}_{3} \mathrm{OH}+\mathrm{HCOO}^{-}$

The reaction (2) was remarkably promoted by the increase of bath temperature above $60^{\circ} \mathrm{C}$ and $\mathrm{pH}$ higher than 12.5. X-ray diffraction data of the powdery deposits which have been obtained by 1 hour mixing of $\mathrm{CuO}$ and $\mathrm{Cu}_{2} \mathrm{O}$ powders with the $\mathrm{Cu}-\mathrm{EDTA}$ bath at $60^{\circ} \mathrm{C}$ showed that the reducing power of the solution containing both formaldehyde and EDTA was higher than that of the solution containing each component separately. In the former case, the added $\mathrm{Cu}_{2} \mathrm{O}$ was completely reduced to metallic copper. This fact suggests that the spontaneous decomposition of the EDTA bath does not occur through the formation of $\mathrm{Cu}_{2} \mathrm{O}$ contrary to the case of Rochelle salt bath, but spontaneous decomposition starts in the bath either by copper particles removed from the surface or by the reduction of metallic copper when the reducing power of the solution increases. The mixed potential theory of the reaction (1) was also studied by potential sweep method.
\end{abstract}

\section{1. 緒 言}

無電解銅めっきの主反応については，析出銅表面上の 局部アノード反応と局部カソード反応による複合電極反 応論もしくは混成電位論が適用され，ロッセル塩浴に関 して斎藤 ${ }^{3}$, EDTA 浴に関して広幡ら ${ }^{4)}$ の詳細な研究が ある。

しかしながら，実際のめっき反応において主反応以外 に起こり得る副反応, 例えば浴の自然分解反応やホルム アルデヒドの不均化反応については未だ不明の点が多

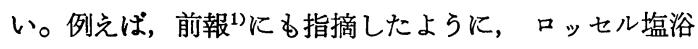
では $\mathrm{Cu}_{2} \mathrm{O}$ のよらな $\mathrm{Cu}(\mathrm{I})$ 化合物の生成が認められる が, EDTA 浴では $\mathrm{Cu}(\mathrm{I})$ の生成が認められない。

また，とくに高温度で操作される高速度無電解銅めっ き浴では, めっき主反応による浴中のホルムアルデヒド の消耗のほかに, 不均化反応としての Cannizzaro 反応 による消耗が著しいるのと予想される。

これらの点を明らかにする目的で, 分析化学的手法と

* 関東学院大学工学部 (下236 横浜市金沢区六浦町 4834) Fac. of Eng., Kanto Gakuin Univ. 4834, Mutsuura-cho, Kanagawa-ku, Yokohama 236
電気化学的手法を用いて EDTA を錯化剂とする 無電解 銅めっき浴中で起こり得る諸反応の機構を追究した。

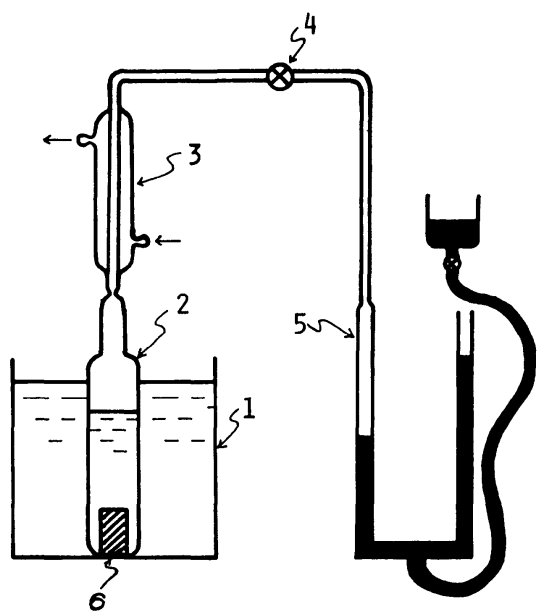

Fig. 1 Apparatus for determination of bath components and reaction products during electroless copper deposition by EDTA bath at $70^{\circ} \mathrm{C}$.

1: Thermo-bath, $2:$ Reactor, 3 : Condenser $4:$ Cock, $5:$ Gas burett, $6:$ Sample to be plated 


\section{2. 実 験 方 法}

\section{2-1 分析化学的手法}

図 1 の装置を用いて，めっき反応中の各成分濃度の変 化を調べた。この装置で，まず恒温槽中にめっき液を含 む反応容器（容量 $100 \mathrm{~m} l$ ) をセットし, 浴温が所定の温 度 $\left( \pm 0.5^{\circ} \mathrm{C}\right)$ になったところで, あらかじめ反応容器上 部内壁に容器の内側と外側から磁石で固定させて抲いた 銅はくを落下させて実験を開始する。同時にめっき反応 が進行して $\mathrm{H}_{2}$ ガスが発生するから，この $\mathrm{H}_{2}$ ガスをガス ビューレットで捕集し，ガス発生量は大気圧に換算して 求めた。溶液中の銅濃度は反応前後の銅はくの重量差に よって求め, $\mathrm{OH}^{-}$濃度は中和滴定により, またホルムフ ルデヒド濃度は亜硫酸ナトリウム法により定量した。

\section{2-2 X楾回折}

めっき浴中の $\mathrm{Cu}(\mathrm{I})$ の定量については前報1) 報告し たが，今回の実験では各種溶液中に $\mathrm{Cu}_{2} \mathrm{O}$ 及び $\mathrm{CuO}$ の 粉未（いずれす和光純薬製試薬）を故意に加えて，1時 間後の反応生成物をとり出しX線回折を行ない，めっき 浴中でのこれらの銅酸化物の安定性を調べた。

\section{2-3 電気化学的手法}

電位-電流 $(\mathrm{V}-i)$ 曲線の測定には，北斗電工製ポテン

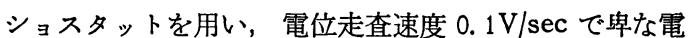
位から貴方向に掃引した。試験電極は $0.5 \mathrm{~mm} \phi$, 表面積 $1 \mathrm{~cm}^{2}$ の $\mathrm{Pt}$ 線にシアン化銅浴で 1 分間めっきしたるの， また，外部分極曲線の測定には，EDTA 基本浴で10分間 めっさしたものを用いた。参照電極は酸化水銀電極で, 溶液はあらかじめ $\mathrm{N}_{2}$ ガスで脱酸素し，測定中はかくは んを行なわなかった。分極曲線測定用試験液としてのめ つ浴組成は, $\mathrm{CuSO}_{4} \cdot 5 \mathrm{H}_{2} \mathrm{O} 0.04 \mathrm{M}$, EDTA 0.1 M, HCHO 0.3M, pH12.5 とした。

\section{3. 実験結果及び考察}

\section{3-1 めっき主反応と副反応}

一般に，無電解銅めっきの反応は，浴中の $\mathrm{Cu}$ (II) 錯 体を $\mathrm{Cu}(\mathrm{II})-\mathrm{Complex}$ と表現するとき，次式で表わさ れる自己触媒反応と考兄れている。

$$
\mathrm{Cu} \text { (II)-complex }+2 \mathrm{HCHO}+4 \mathrm{OH}^{-}
$$

$$
\rightarrow \mathrm{Cu}^{\circ}+2 \mathrm{HCOO}^{-}+\mathrm{H}_{2}+2 \mathrm{H}_{2} \mathrm{O}+\text { Complex } \cdots(1)
$$

またこの反応は，析出銅表面でのホルムアルデヒドの アノード酸化反応と $\mathrm{Cu}(\mathrm{II})$ イオンの カソード還元反応 の合成による複合電極反応であることが実証されてい $3^{3), 4), 5) 。}$

実際にはこのほか汪，Cannizzaro 反応として知られ る副反応により，浴中のホ

\begin{tabular}{|c|c|c|c|c|c|c|}
\hline \multirow{2}{*}{ Type of baths } & \multicolumn{6}{|c|}{ Reacted amount $\times 10^{-2} \mathrm{~mol}$} \\
\hline & $\mathrm{A}: \mathrm{Cu}$ & $\mathrm{B}: \mathrm{HCHO}$ & $\mathrm{B}^{\prime}: \mathrm{HCHO}$ & $\mathrm{C}: \mathrm{OH}^{-}$ & $\mathrm{C}^{\prime}: \mathrm{OH}^{-}$ & $\mathrm{D}: \mathrm{H}_{2}$ \\
\hline No. 1 & 1.9 & 18.6 & 14.8 & 15.1 & 7.4 & 1.9 \\
\hline$E=B-B^{\prime}$ & \multirow{2}{*}{\multicolumn{3}{|c|}{3.8}} & & & \\
\hline $\mathrm{F}=\mathrm{C}-\mathrm{C}^{\prime}$ & & & & \multicolumn{2}{|c|}{7.7} & \\
\hline$A: E: F: D$ & (1) & \multicolumn{2}{|c|}{ (2) } & \multicolumn{2}{|c|}{ (4) } & (1) \\
\hline $\mathrm{B}^{\prime}: \mathrm{C}^{\prime}$ & & & (2) & & (1) & \\
\hline No. 2 & 1.6 & 14.5 & 11.3 & 12.1 & 5.7 & 1.6 \\
\hline $\mathrm{E}=\mathrm{B}-\mathrm{B}^{\prime}$ & \multirow{2}{*}{\multicolumn{3}{|c|}{3.2}} & & & \\
\hline$F=C-C^{\prime}$ & & & & \multicolumn{2}{|c|}{6.4} & \\
\hline$A: E: F: D$ & (1) & \multicolumn{2}{|c|}{ (2) } & \multicolumn{2}{|c|}{ (4) } & (1) \\
\hline $\mathrm{B}^{\prime}: \mathrm{C}^{\prime}$ & & & (2) & & (1) & \\
\hline No. 3 & 1.7 & 14.5 & 11.1 & 11.9 & 5.5 & 1.7 \\
\hline $\mathrm{E}=\mathrm{B}-\mathrm{B}^{\prime}$ & & \multicolumn{2}{|c|}{3.4} & & & \\
\hline $\mathrm{F}=\mathrm{C}-\mathrm{C}^{\prime}$ & & \multirow{2}{*}{\multicolumn{2}{|c|}{ (2) }} & \multirow{2}{*}{\multicolumn{2}{|c|}{6.4}} & \\
\hline$A: E: F: D$ & (1) & & & & & (1) \\
\hline $\mathrm{B}^{\prime}: \mathrm{C}^{\prime}$ & & & (2) & & (1) & \\
\hline
\end{tabular}

Table 1 Reacted amount of the bath components.

Type of baths

No. $1: 0.04 \mathrm{M} \mathrm{CuSO}_{4} \cdot 5 \mathrm{H}_{2} \mathrm{O}+0.1 \mathrm{M}$ EDTA $+0.3 \mathrm{M} \mathrm{HCHO}(\mathrm{pH} 12.5)$

No. 2 : No. $1+$ Dipyridy $110 \mathrm{mg} / 1+$ Sodium nitroprusside $10 \mathrm{mg} / 1$

No. 3 : No. $1+\mathrm{K}_{2} \mathrm{Ni}(\mathrm{CN})_{4} \quad 10 \mathrm{mg} / 1+$ Dipyridy $1 \quad 10 \mathrm{mg} / 1$

A, B, C, D : Reacted amount during plating reaction

B', C' : Reacted amount without plating reaction

E : Amount of $\mathrm{HCHO}$ consumed by plating reaction

F : Amount of $\mathrm{OH}$ consumed by plating reaction
ルムアルデヒドがギ酸に変 化する。

$$
\begin{aligned}
& 2 \mathrm{HCHO}+\mathrm{OH}^{-} \\
& \quad \rightarrow \mathrm{CH}_{3} \mathrm{OH}+\mathrm{HCOO}^{-}
\end{aligned}
$$

この反応は室温に招いて は，(1)の主反応に比べてほ とんど無視し得るが，高温 度での高速度めっきの条件 では，かなりの速度で起こ り得ることが予想される。

図1の装置を用いて, $70^{\circ} \mathrm{C}$ でめっき反応を行な ったときのそれぞれの基本 浴成分の反応量と，ぬっき 反応をさせないときの(2)式 による反応量の測定結果を 表 1 に示した。反応時間は いずれす 1 時間とした。

表 1 に沏いて，めっきを 行なったときの $\mathrm{HCHO} の$ 反応量 $\mathrm{B}$ と同じく $\mathrm{OH}^{-}$の 反応量Cは(1)式と(2)式によ る反応量の合計であるか ら，(1)式のみによるHCHO 


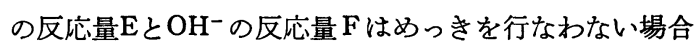
の(2)式の $\mathrm{HCHO}$ の反応量 $\mathrm{B}^{\prime}$ と $\mathrm{OH}^{-}$の反応量 $\mathrm{C}^{\prime}$ を求め, それらの值から, $\mathrm{E}=\mathrm{B}-\mathrm{B}^{\prime}, \mathrm{F}=\mathrm{C}-\mathrm{C}^{\prime}$ によって求める ことがでさる。その結果, 浴の種類にかかわらずめっき 反応に拈ける $\mathrm{Cu}, \mathrm{HCHO}, \mathrm{OH}^{-}$及び $\mathrm{H}_{2}$ の反応量比率は, $\mathrm{Cu}$ 反応量を 1として 1：2：4：1であり, 反応式(1)の 正当性が確認された。

また，反応を行なわない場合の $\mathrm{HCHO}$ と $\mathrm{OH}^{-}$反応 量比率は $2 ： 1$ であり, Cannizzaro 反応として知られ る(2)式によるホルムアルデヒドの自己分解反応であるこ とが確認できた。表 1 に拈けるホルムアルデヒドの反応 量 $\mathrm{E}$ と $\mathrm{B}^{\prime}$ を比較すれば, $70^{\circ} \mathrm{C}$ の高温度に执いてはホル ムアルデヒドの消耗は(1)式のめっき反応よりる，むしろ (2)式による自己分解反応の方が大さく，しかもそれは前 者の 3〜 4 倍の速さで進行することがわかる。

次に, Cannizzaro 反応によるホルムアルデヒドの分 解反応の温度と $\mathrm{pH}$ 依存性について調べ, 図 2 の結果を 得た。この結果から, めっき浴の温度と $\mathrm{pH}$ の上昇に伴 い, ホルムアルデヒドの分解反応が生じやすくなること がわかる。この傾向はとくに $60^{\circ} \mathrm{C}$ 以上の高温度で著し w。

\section{3-2 めっき浴中における銅酸化物の安定性}

一般に，(1)式のめっき反応，(2)式のホルムアルデヒ ドの分解反応のほかに次に示す自然分解反応も生じる と説明されている。

まず，次式により浴中に $\mathrm{Cu}_{2} \mathrm{O}$ を生じる。

$$
2 \mathrm{Cu}^{2+}+\mathrm{HCHO}+5 \mathrm{OH}^{-} \rightarrow \mathrm{Cu}_{2} \mathrm{O}+\mathrm{HCOO}^{-}+3 \mathrm{H}_{2} \mathrm{O}
$$

(3)式により生成された $\mathrm{Cu}_{2} \mathrm{O}$ は, さらに次の(4)式に よる不均化反応：

$$
\mathrm{Cu}_{2} \mathrm{O}+\mathrm{H}_{2} \mathrm{O} \rightleftarrows \mathrm{Cu}^{\circ}+\mathrm{Cu}^{2+}+\mathrm{H}_{2} \mathrm{O}
$$

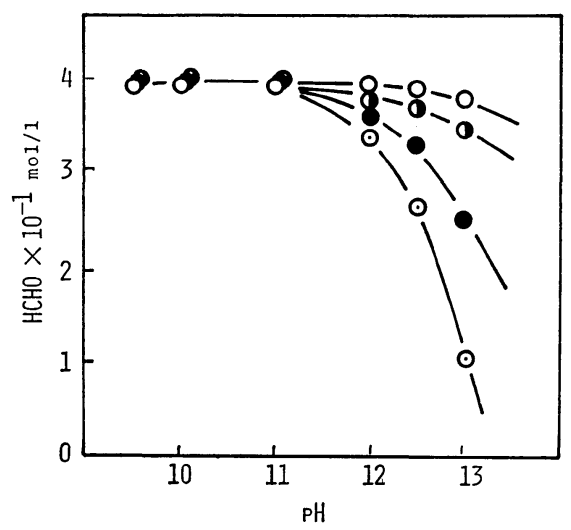

Bath temperature $0 ; 25^{\circ} \mathrm{C} 0 ; 40^{\circ} \mathrm{C} \bullet ; 60^{\circ} \mathrm{C} \quad 0 ; 70^{\circ} \mathrm{C}$

Fig. 2 Effects of temperature and $\mathrm{pH}$ on decomposition of formaldehyde by Cannizzaro reaction.
すしくは，(5)式による活性 $\mathrm{Cu}$ 核の生成, さらにこれ らの核上で主反応(1)を生じて分解する。

$$
\begin{aligned}
\mathrm{Cu}_{2} \mathrm{O} & +2 \mathrm{HCHO}+2 \mathrm{OH}^{-} \\
& \rightarrow 2 \mathrm{Cu}+\mathrm{H}_{2}+2 \mathrm{HCOO}^{-}+\mathrm{H}_{2} \mathrm{O}
\end{aligned}
$$

上述のように，これらはロッセル塩浴の反応に相当す るフェーリング反応の延長として類推されたものであ る。しかしながら，前報1に報告したよらに，(3)式を支 持する $\mathrm{Cu}(\mathrm{I})$ の存在はロッセル塩浴では確認されるが, EDTA 浴では確認されなかった。

めっき浴または析出銅表面に拈ける $\mathrm{Cu}_{2} \mathrm{O}$ の存在が， 無電解銅めっき浴の安定性やめっき膜の延性に関係する という考え方もあり, 浴中の $\mathrm{Cu}_{2} \mathrm{O}$ の挙動はめっき浴の 反応の基本的理解に重要な問題となるので, それを調べ るために次のような実験を行なった。すなわち, i ) 0.1M EDTA 溶液, ii) $0.3 \mathrm{M} \mathrm{HCHO}$ 溶液 iii) 0.1M EDTA+ $0.3 \mathrm{M} \mathrm{HCHO}$ 溶液の三種類の溶液 $100 \mathrm{~m} l$ 中に $\mathrm{Cu}_{2} \mathrm{O}$ ま

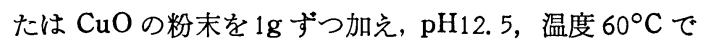
1 時間反応させ，反応後の粉末をX線回折して，これら 銅酸化物のめっき浴中に拈ける安定性について調へ，図 3 の結果を得た。

還元剤としてのホルムアルデヒドを含まない $0.1 \mathrm{M}$
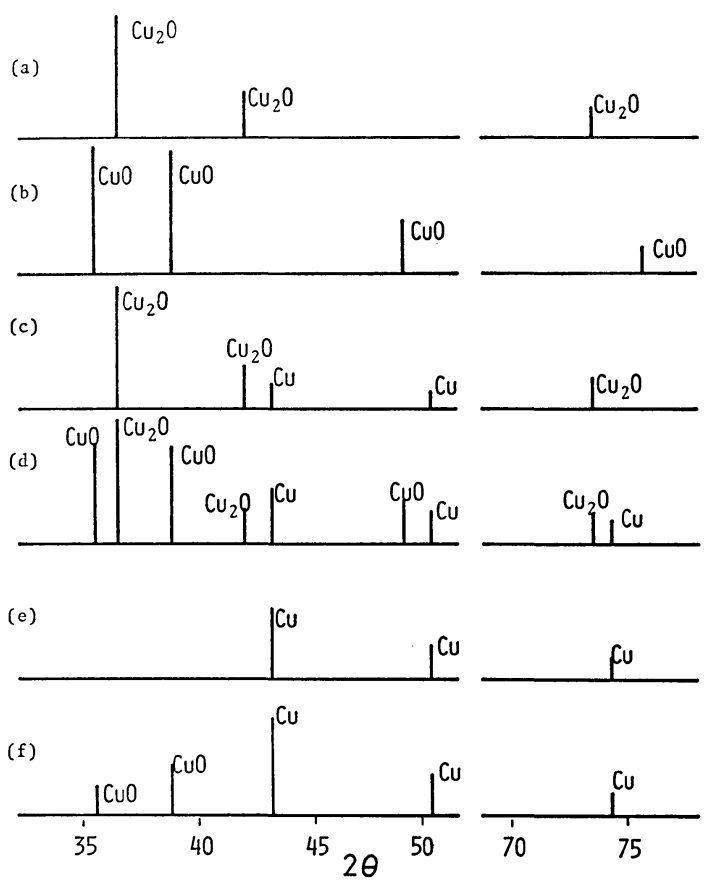

Fig. $3 \mathrm{X}$-ray diffraction patterns of $\mathrm{CuO}, \mathrm{Cu}_{2} \mathrm{O}$, and $\mathrm{Cu}$.

(a) $\mathrm{Cu}_{2} \mathrm{O}+0.1 \mathrm{M}$ EDTA (b)CuO+0.1M EDTA (c) $\mathrm{Cu}_{2} \mathrm{O}+0.3 \mathrm{M} \mathrm{HCHO}$ (d) $\mathrm{CuO}+0.3 \mathrm{M} \mathrm{HCHO}$ (e) $\mathrm{Cu}_{2} \mathrm{O}+0.1 \mathrm{M}$ EDTA +0.3M HCHO (f) $\mathrm{CuO}+0.1 \mathrm{M}$ EDTA + 0.3M HCHO 
EDTA 溶液中では, $\mathrm{Cu}_{2} \mathrm{O}$ も $\mathrm{CuO}$ も何ら変化を受けな いが，0.3M HCHO溶液中では，いずれすある程度金属 銅に還元されていることがわかる。CuO を加えた場合 には反応後の試料に $\mathrm{Cu}$ とともに $\mathrm{Cu}_{2} \mathrm{O}$ の回折線が認め られ， $\mathrm{CuO}$ が $\mathrm{Cu}_{2} \mathrm{O}$ を経て $\mathrm{Cu}$ に還元されることを示唆 している。

次に還元剤とキレート剤の 共存する $0.1 \mathrm{M} \mathrm{EDTA} \mathrm{+}$ $0.3 \mathrm{M} \mathrm{HCHO}$ 溶液では, 還元性が非常に強く $\mathrm{Cu}_{2} \mathrm{O}$ はす べて $\mathrm{Cu}$ に還元されており，CuOの場合にはわずかに $\mathrm{CuO}$ が残留するが，他はすべて 金属銅に還元されてい る。このようにホルムアルデヒドのみを単独に含む溶液 よりす，ホルムアルデヒドと EDTA の共存する 溶液の 還元性が強い事実は注目に価する。また，両者が共存す る溶液中で $\mathrm{Cu}_{2} \mathrm{O}$ の存在が認められない事実は，前報の

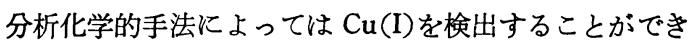

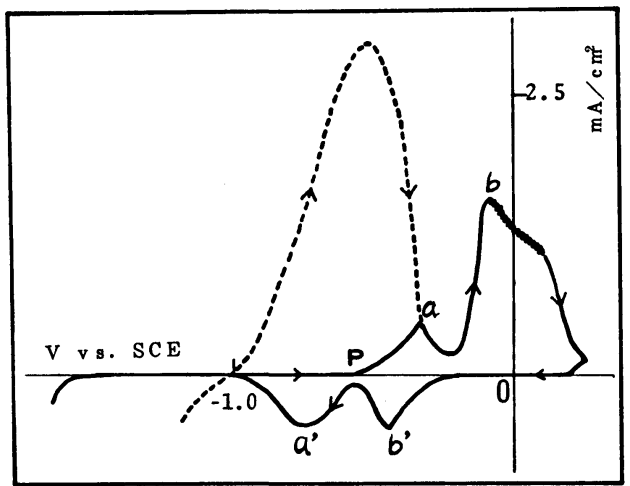

Fig. 4 Cyclic voltammograms with a copper electrode in $\mathrm{NaOH}, \mathrm{pH} 13$ solution (solid line) and in $\mathrm{NaOH}+0.25 \mathrm{M}$ formaldehyde, $\mathrm{pH}$ 13 solution (dotted line) at $20^{\circ} \mathrm{C}$, sweep rate $0.01 \mathrm{~V} / \mathrm{sec}^{3)}$.

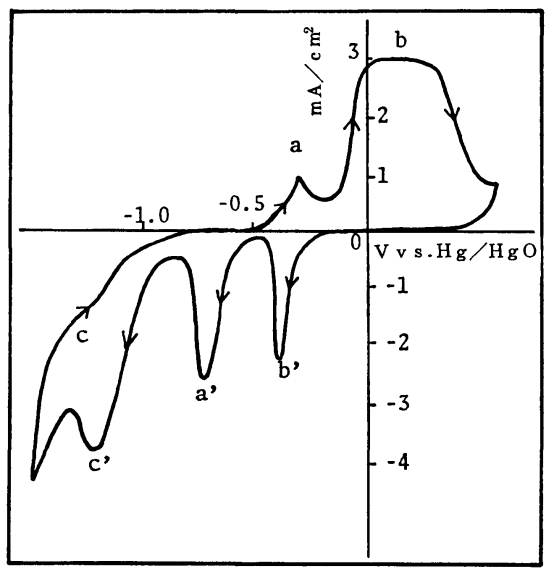

Fig. 5 Cyclic voltammogram with a copper electrode in $\mathrm{Cu}$ (II)-EDTA solution $(0.04 \mathrm{M}$ $\mathrm{CuSO}_{4}, 0.1 \mathrm{M}$ EDTA, $\left.\mathrm{pH} 12.5\right)$ at $25^{\circ} \mathrm{C}$.
なかった事実を裏づけるものである。

したがってって， EDTA 浴に批りる自然分解反応で は，(3)式の $\mathrm{Cu}_{2} \mathrm{O}$ 生成反応を経るとしても，反応はきわ めて速く，ロッセル塩浴の場合のよ5に $\mathrm{Cu}_{2} \mathrm{O}$ の生成を 認めることはできない。したがって EDTA 浴では，め っき面から Cu 粒子が脱落して，めっき面以外の場所で (1)の反応を生じるか，あるいはきわめて還元性の強い高 濃度, 高温の条件では, 容器壁または溶液内部に执いて 直接金属銅への還元反応を生じるが，ロッセル塩浴の場 合のように黄緑色ないしかっ色の $\mathrm{Cu}_{2} \mathrm{O}$ 生成を認めるこ とはできない。

\section{3-3 EDTA 浴における混成電位論}

さきに著者は無電解銅めっきに関する電気化学的研究 を行ない，ロッセル塩浴ではそれぞれ単独に求めたホル ムアルデヒドのアノード分極曲線と $\mathrm{Cu}(\mathrm{II})$ 錯体のカソ 一ド分極曲線の合成が，めっき浴について求めた外部分 極曲線とほぼ一致するが，EDTAを多量に含む浴では外 部分極曲線と $\mathrm{Cu}(\mathrm{II})-\mathrm{EDTA}$ 錯体のカソード分極曲線が 明らかに一致せず，ホルムアルデヒドを含まない $\mathrm{Cu}(\mathrm{II})$ -EDTA 錯体からのカソード反応がきわめて不活性であ ること，すなわち観測されるカソード電流は，ホルムア ルデヒドの酸化電位領域内できわめて小さいことを指 摘した ${ }^{8)}$ 。この理由としてホルムアルデヒドと $\mathrm{Cu}(\mathrm{II})-$ EDTA 錯体との共存によるなんらかの 励起作用による と考觉た。

一方，広幡らは4)，この現象をそれぞれの V- $i$ 曲線を 測定するときの銅電極表面の活性度の差によって説明し た。すなわち，ホルムアルデヒドを含まない $\mathrm{Cu}(\mathrm{II})-$ EDTA 錯体溶液中の電極表面は $\mathrm{Cu}_{2} \mathrm{O}$ によって拈括われ て拈り，したがってこの液から得られる局部カソード分 極曲線は不活性電極によるるのであるから，めっき浴か ら得られる活性電極上の外部分極曲線に対する局部カン 一ド分極曲線とは異なると説明した。しかしながら，ア ルカリ溶夜中での銅電極上の $\mathrm{Cu}_{2} \mathrm{O}$ 生成反応は次式で表

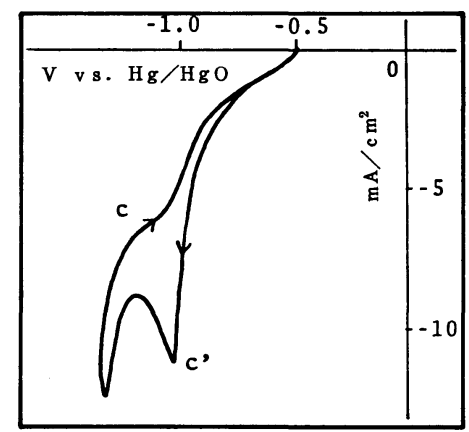

Fig. 6 Cyclic voltammogram with a copper electrode in $\mathrm{Cu}$ (II)-EDTA solution $(0.04 \mathrm{M}$ $\mathrm{CuSO}_{4}, 0.1 \mathrm{M}$ EDTA, pH12.5)at $60^{\circ} \mathrm{C}$. 
わされ(6),

$$
\begin{aligned}
& 2 \mathrm{Cu}+2 \mathrm{OH}^{-} \rightleftarrows \mathrm{Cu}_{2} \mathrm{O}+\mathrm{H}_{2} \mathrm{O}+2 \mathrm{e}, \\
& \mathrm{E}=0.468 \mathrm{~V}-0.058 \mathrm{pH}(\mathrm{V} \text { vs. } \mathrm{SCE}), 20^{\circ} \mathrm{C}
\end{aligned}
$$

銅電極表面が $\mathrm{Cu}_{2} \mathrm{O}$ によってお怙われることにより， ホルムアルデヒドのアノード酸化反応が停止することが 明らかにされているる゙。すなわち，図4の実線はホルム アルデヒドを含まない $\mathrm{pH} 13$ の $\mathrm{NaOH}$ 溶液中での銅電極 のアノード分極特性で，卑から貴方向に電位走査すると きのアノード電流ピーク $\mathrm{a} は \mathrm{Cu}_{2} \mathrm{O}$ の生成，bはそれに 続く $\mathrm{CuO}$ の生成に上る不働態化現象を示し, 電位走査 方向反転後のカソード電流ピーク $\mathrm{b}^{\prime}$ と $\mathrm{a}^{\prime}$ は, それぞれ $\mathrm{CuO}$ と $\mathrm{Cu}_{2} \mathrm{O}$ の還元電流である。

また，点線はホルムアルデヒドを含む溶液でのカソー ド分極特性で，銅電極表面が $\mathrm{Cu}_{2} \mathrm{O}$ の生成により不働態 化するとホルムアルデヒドの酸化反応が停止する様子を 示している。

また，図 4 実線の電位走査で，はじめに十分卑な電位 から貴方向に電位走査するとき，ピーク a を過ぎた点で 走査方向を反転させれば, 明らかに $\mathrm{Cu}_{2} \mathrm{O}$ の還元電流で あるピーク $\mathrm{a}^{\prime}$ のみが現われる。

すなわち，図の $\mathrm{p}$ 点より卑電位側では銅電極は活性域 にある。

図 5 にホルムアルデヒドを含まないCu(II)-EDTA 溶 液での銅電極の分極特性を示した。十分卑な電位から貴 方向に電位走查すれば，まず $\mathrm{Cu}(\mathrm{II})$ の還元波 $\mathrm{c}$ が認め られるが， $-0.5 \mathrm{~V}$ 付近からアノード電流が流れ，a と bのピーク電流が認められる。この曲線は $\mathrm{Cu}(\mathrm{II})$ の還 元波 $\mathrm{c}$ の存在を除けば図 4 の実線と類似しており、aは $\mathrm{Cu}_{2} \mathrm{O}$ の生成, $\mathrm{b}$ は $\mathrm{Cu}_{2} \mathrm{O}$ から $\mathrm{CuO}$ の生成による不働態 化と解釈される。電位走查方向反転後のピーク $\mathrm{b}^{\prime}, \mathrm{a}^{\prime}$ 及 び $\mathrm{c}^{\prime}$ は，それぞれ $\mathrm{CuO}, \mathrm{Cu}_{2} \mathrm{O}, \mathrm{Cu}(\mathrm{II})$ の還元波である。 これより明らかなように，卑から貴方向に電位走査する ときの $\mathrm{Cu}(\mathrm{II})$ の還元波 $\mathrm{c}$ ，つまりホルムアルデヒドを

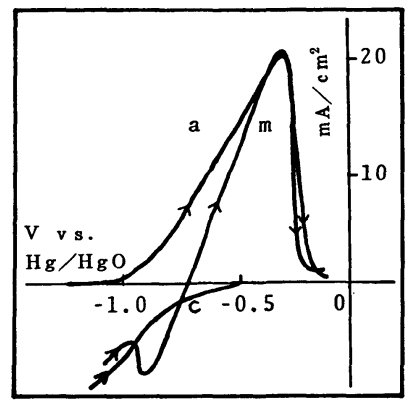

Fig. 7 V-i curves

$$
\begin{aligned}
& \text { a }: 0.3 \mathrm{M} \mathrm{HCHO}, \mathrm{pH} 12.5,60^{\circ} \mathrm{C} \\
& \mathrm{m}: 0.04 \mathrm{M} \mathrm{CuSO} \\
&, 0.1 \mathrm{M} \mathrm{EDTA}, 0.3 \mathrm{M} \\
& \mathrm{HCHO}, \mathrm{pH}_{12} .5,60^{\circ} \mathrm{C} \\
& \text { c }: 0.04 \mathrm{M} \mathrm{CuSO}_{2}, 0.1 \mathrm{M} \text { EDTA, PH} 12.5,60^{\circ} \mathrm{C}
\end{aligned}
$$

含まない $\mathrm{Cu}(\mathrm{II})-\mathrm{EDTA}$ 溶液から得られる局部カソード 分極曲線は，表面に銅酸化物のない活性銅電極によるも のである。

次に高速度無電解銅めっきに相当する高温度の条件で 卑電位から貴電位側に電位走査し， $\mathrm{Cu}_{2} \mathrm{O}$ が生成する直 前の電位で反転させたとさの $\mathrm{E}-i$ 曲線を図 6 亿示した。 この場合には $\mathrm{Cu}(\mathrm{II})$ の還元波のみが観察され，図 5 の ような酸化物の還元波は現われない。また， $\mathrm{Cu}(\mathrm{II}) の$ 還元波に走査方向によって相違が見られるのは，この種 の測定に当然認められる現象である。

以上の結果は，ホルムアルデヒドを含まない $\mathrm{Cu}(\mathrm{II})-$ EDTA 溶液から得られる局部カソード分極曲線が，活 性銅電極上のものであることを証明する。そこで炊に， $60^{\circ} \mathrm{C}$ の電位走查法で得られるホルムアルデヒドの酸化 反応(局部アノード分極曲線a), 図 6 の Cu(II)-EDTA 錯体の還元反応（局部カソード分極曲線 c ）及びめっき 液について得られる外部分極曲線 $\mathrm{m}$ 同一のグラフに記 入すると図7が得られる。この図で，ホルムアルデヒド 溶液から求められる局部アノード分極曲線 $\mathrm{a}$ と外部分極 曲線mのアノード電流部分の形状と大きさはよく一致す るから，めっき反応の局部アノード分極曲線は $\mathrm{a}$ に相当 するすのと考えてよい。しかし今まで指摘されている

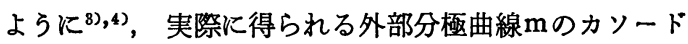
電流部分とホルムアルデヒドを含まない $\mathrm{Cu}$ (II)-EDTA 錯体から求めた局部カソード分極曲線 $\mathrm{c}$ の不一致は著し く, 図7 の局部アノード分極曲線 $\mathrm{a}$ と局部カソード分極 曲線 $\mathrm{c}$ の単純な合成からは外部分極曲線の混成電位の位 置もカソード電流部分の形状も予測できない。そこで逆

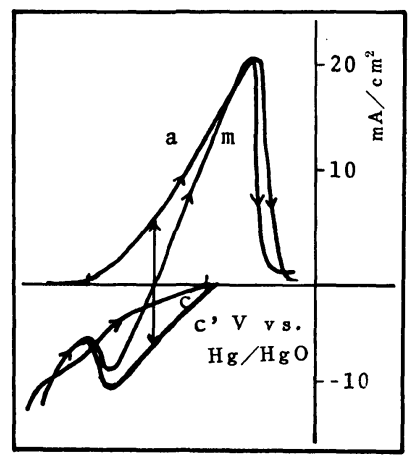

Fig. 8 Mixed potential model for EDTA bath. a : Anodic polarization curve of formaldehyde(the same a in Fig. 7)

$\mathrm{m}$ : Mixed polarization curve obtained in plating bath(the same $\mathrm{m}$ in Fig. 7)

c : Cathodic polarization curve of $\mathrm{Cu}$ (II) -EDTA complex (the same c in Fig. 7)

$c^{\prime}$ : Cathodic polarization curve presumed from $a$ and $m$ 
に，図8のように外部分極曲線 $\mathrm{m}$ と局部アノード分極曲 線、から，これらに対応すべき局部カソード分極曲線を 逆算して求めると曲線 $\mathbf{c}^{\prime}$ が得られる。混成電位に扑け る局部アノード電流密度 ia と局部カソード電流密度 ic の間には $\mid$ ia $|=|$ ic $\mid=I_{0}$ の関係があり, 図8からめっき 電流密度 $I_{0}$ を求めると約 $6 \mathrm{~mA}$ である。これを単位面積 当りの析出量に換算すると，約 $7 \mathrm{mg} / \mathrm{cm}^{2} / \mathrm{h}$ になり，別 の実験で求めた同一条件での重量法による析出速度（約 $\left.6 \mathrm{mg} / \mathrm{cm}^{2} / \mathrm{h}\right)$ にだいたい一致する。

なお，特に高温度の場合には，電気化学的方法が瞬間 的に反応速度をとらえるのに対して，重量法では測定時 間内にホルムアルデヒドの濃度減少が起こるから, 両者 の結果の相違は当然といえる。したがって，実際のめっ き反応での外部分極曲線に対応する局部カソード分極曲 線は，ホルムアルデヒドと EDTA の共存によって溶液 の還元性が異常に高まり, その結果, 単独溶液でのカソ 一ド還元反応 c が $c^{\prime}$ に活性化されたものと考える。

\section{4. 結 論}

EDTA浴による高速度無電解銅めっきの反応機構につ いて, 分析化学的手法, X線回折法及び電気化学的手法 を用いて調べ，次のような結論を得た。

(1) $60^{\circ} \mathrm{C}$ でめっき反応を行なわせるときの主要成分 濃度の変化と水素発生量を分析化学的手法によって求 め, 高温度での無電解銅めっき浴中での反応が次式によ ることを化学量論的に確認した。

i めっき反応

$$
\begin{aligned}
& \mathrm{Cu}(\mathrm{II})-\mathrm{EDTA}+2 \mathrm{HCHO}+4 \mathrm{OH}^{-} \\
& \rightarrow \mathrm{Cu}+2 \mathrm{HCOO}^{-}+\mathrm{H}_{2}+2 \mathrm{H}_{2} \mathrm{O}+\mathrm{EDTA} \quad \cdots(1)
\end{aligned}
$$

ii ホルムアルデヒドの分解反応

$$
2 \mathrm{HCHO}+\mathrm{OH}^{-} \rightarrow \mathrm{CH}_{3} \mathrm{OH}+\mathrm{HCOO}^{-}
$$

(2) ホルムアルデヒド溶液, EDTA 溶液及びホルムア ルデヒド+EDTA 溶液中に $\mathrm{Cu}_{2} \mathrm{O}$ と $\mathrm{CuO}$ 粉末をそれぞ れ故意に加えて $60^{\circ} \mathrm{C} て ゙ 反$ 応させ，反応後の粉末をX線
回折した。その結果，ホルムアルデヒドと EDTA の共 存する溶液の還元性はそれぞれ単独成分溶液のそれに比 べて著しく強く， $\mathrm{Cu}_{2} \mathrm{O}$ はすべて金属銅に還元された。

この事実と前報1で報告したEDTA 浴における $\mathrm{Cu}(\mathrm{I})$ の挙動から, 従来フェーリング反応の延長として提案さ れてきた $\mathrm{Cu}_{2} \mathrm{O}$ 生成型のめっき浴の自然分解反応機構 は，EDTA 浴では成立せず，EDTA 浴ではめっき面か らの脱落銅粒子による析出銅脱離型分解をたは金属銅直 接還元型分解が起こると考えられる。

（3） EDTA浴による無電解銅めっき反応に混成電位論 を適用するとさ，外部分極曲線から予想される局部カソ 一ド分極曲線と，ホルムアルデヒドを含まない $\mathrm{Cu}(\mathrm{II})-$ EDTA 錯体溶液から得られる局部カソード分極曲線 と の著しい不一致は，両者を測定するときの銅電極表面の 活性度の相異によるものではなく，ホルムアルデヒドの EDTAの共存による溶液の還元性の増大に起因すると結 論した。（本報の一部は昭和48年10月本協会第48回学術 講演大会にて発表)

(1977-10-31 受理)

\section{文献}

1）斎藤囲，本間英夫；高速度無電解銅めっき浴 中の $\mathrm{Cu}$ (I)の挙動, 本誌, 29，88（1978）

2）斎藤囲，本間英夫；EDTA 浴による高速度無電解銅 めっきの反応機構，本誌，29，190 (1978)

3) 斎藤囲; 化学銅めっきの電気化学的研究, 本誌, 16, 300 (1965), 17, 14, 258, 264 (1966)

4) 厇幡兵伍; 無電解銅めっきに関する研究, 本誌, $21,20,73,142,485,550$ (1970), 23, 393, 465 (1972)

5) M.Paunovic ; Electrochemical Aspects of Electroless Deposition of Metals, Plating, 55, 1161 (19 68)

6) M.Pourbaix ; Thermsdynamics of Dilute Aqueous Solutions, Edwards Arnord Co. (1949) 